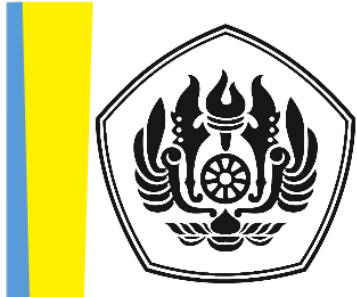

JURNAL POROS HUKUM PADJADJARAN

P-ISSN: 2715-7202 E-ISSN: 2715-9418

Artikel diterbitkan: 30 November 2020

DOI:

https://doi.org/10.23920/jphp .v2i1.264

Halaman Publikasi: http://jurnal.fh.unpad.ac.id/i ndex.php/JPHP/issue/archive

Diterbitkan oleh: Fakultas Hukum Universitas Padjadjaran

\title{
ANALISIS YURIDIS HAK EIGENDOM VERPONDING SEBAGAI JAMINAN KEBENDAAN
}

\section{JURIDICAL ANALYSIS OF VERPONDING EIGENDOM RIGHTS AS A GUARANTEE OF FITNESS}

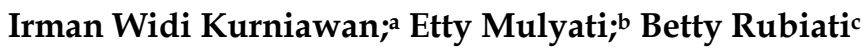

\begin{abstract}
ABSTRAK
Di dalam bagian kedua UUPA mengatur tentang pelaksanaan konversi hak atas tanah menjadi wujud kepastian hukum sebagaimana ketentuan Pasal 33 ayat (3) UUD 1945. Namun kepastian hukum terhadap konversi Hak atas tanah barat terutama sertifikat Hak Eigendom Verponding masih menjadi problematika tersendiri bagi masyarakat yang memiliki bukti kepemilikan hak atas tanah barat tersebut apabila dijadikan sebuah jaminan guna memperoleh fasilitas kredit. Metode penelitian yang digunakan ialah yuridis normatif dengan kajian bahan hukum primer, sekunder serta tersier. Berdasarkan pembahasan tersebut bahwa Kepastian Hukum terkait konversi hak Eigendom Verponding telah memiliki kekuatan hukum mengikat dengan ketentuan diperlukan konversi sehingga dapat dijadikan objek jaminan namun dalam prakteknya masih terdapat objek jaminan dengan tidak memperhatikan asal mula objek jaminan tersebut serta akibat hukum terhadap konversi hak atas tanah tersebut adalah pemberlakuan UUPA menjadi dasar bahwasanya prinsip status quo hak atas tanah terdahulu memberikan jaminan kepastian hukum dengan ketentuan hak-hak lama menjadi tidak diakui keberadaannya.
\end{abstract}

Kata kunci: hak katas tanah; hak barat; kepastian hukum jaminan; konversi.

\begin{abstract}
In the second section of the UUPA regulates the conversion of land rights into a form of legal certainty as stipulated in Article 33 paragraph (3) of the 1945 Constitution. But the legal certainty of the conversion of the Right to western land, especially the Eigendom Verponding Rights certificate, remains a problem for people who have proof of ownership of the western land if it is used as a guarantee to obtain credit facilities. The research method used is normative juridical with the study of primary, secondary and tertiary legal materials. Based on the discussion that legal certainty related to the conversion of rights Eigendom Verponding has had a binding legal force with the necessary provisions of conversion so that it can be used as an object of guarantee but in practice there is still an object of guarantee by not taking into account the origin
\end{abstract}

\footnotetext{
a Magister Ilmu Hukum Fakultas Hukum Universitas Padjadjaran, Jl. Banda No. 42 Bandung, email: irmanwidikurniawan@gmail.com

b Fakultas Hukum Universitas Padjadjaran, Jalan Raya Bandung Sumedang KM. 21 Jatinangor, email: etty.mulyati@unpad.ac.id

c Fakultas Hukum Universitas Padjadjaran, Jalan Raya Bandung Sumedang KM. 21 Jatinangor, email: betty.rubiati@unpad.ac.id
} 
of the object of the guarantee and the legal consequences of the conversion of the right to land is the enactment of the UUPA being the basis that the principle of the status quo of the former land rights provides a guarantee of legal certainty with the provisions of old rights to be unclaimed civility.

Keywords: convertion; guarantee legal certainty; land rights; western rights.

\section{PENDAHULUAN}

Memasuki era pembangunan perekonomian nasional seperti saat ini, manusia pada masa saat ini sedang berusaha untuk mendapatkan sebuah keuntungan perekonomian guna menunjang taraf hidup didalam kehidupannya. Hal ini pula yang memberikan keterikatan antara manusia dengan lingkungan sekitar termasuk tanah. Hubungan manusia dengan tanah sangat memiliki keterikatan satu sama lain. Tanah bukan hanya dilihat sebagai suatu benda tidak bergerak yang bernilai ekonomis, tetapi banyak hal-hal lain yang mempengaruhi hubungan antara manusia dengan tanah salah satunya yaitu adat istiadat serta budaya manusia. ${ }^{1}$ Oleh sebab itu hubungan antara manusia dengan tanah memerlukan sebuah ketentuan hukum yang mengatur hubungan tersebut agar terciptanya suatu kepastian hukum bagi manusia dengan tanah.

Sebagaimana dijelaskan didalam Pasal 2 Ayat (2) Undang-Undang Nomor 5 Tahun 1960 tentang Peraturan Dasar Pokok-Pokok Agraria (yang untuk selanjutnya disingkat UUPA) menjelaskan bahwasanya rakyat Indonesia sebagai pemegang hak tertinggi yang dikuasakan kepada Negara Republik Indonesia sebagai organisasi kekuasaan seluruh rakyat sebagaimana ketentuan didalam Pasal 33 ayat (3) UndangUndang Dasar (yang untuk selanjutnya disingkat UUD). Karena itu, instrumen hukum yang digunakan untuk mendorong paradigma pembangunan ekonomi seperti dimaksud tersebut cenderung bercorak sentralistik, sektoral, memihak kepada pemodal besar (capital oriented), eksploitatif, dan bernuansa represif dengan menggunakan pendekatan sekuriti (security approach). ${ }^{2}$ Hal tersebut mengandung irah-irah berlakunya UUPA sebagai pembaharuan dalam bidang hukum pertanahan nasional sehingga berpengaruh terhadap semua pengaturan yang berkaitan dengan hukum agraria nasional, dengan maksud memberikan jaminan hak-hak bagi para pihak dan menjamin

\footnotetext{
1 Peran tanah sangat besar dan sangat penting bagi kehidupan manusia maka perlu adanya perlindungan hukum dari negara bagi penguasaan hak atas tanah, sehingga hal itu diatur dalam Pasal 33 Ayat (3) UUD NRI 1945 yang menyatakan bahwa "Bumi, air, dan kekayaan alam yang terkandung didalamnya dikuasai oleh negara dan dipergunakan untuk sebesar-besar kemakmuran rakyat", diakses dari Adzini, Danica. (2019). Status Hak Atas Tanah Hasil Okupasi Tentara Nasional Indonesia dan Sertipikat Hak Milik Hasil Konversi. Jurnal Jurist Diction, 2(4), 1196.

2 Nugroho, Wahyu. (2017). Rekontruksi Teori Hukum Pembangunan Kedalam Pembentukan Perundang-Undangan Lingkungan Hidup dan Sumber Daya Alam Pasca Reformasi Dalam Bangunan Negara Hukum. Jurnal Legislasi Indonesia, 14(4), 371.
} 
perlindungan hukum bagi subyek hukum tertentu agar memperoleh suatu kepastian hukum. ${ }^{3}$

Untuk memperkuat kedudukan subyek hukum kepemilikan hak atas tanah. Hak atas tanah dapat dibuktikan dengan sertipikat hak atas tanah, yang memuat data fisik dan data yuridis di dalamnya, sepanjang data fisik dan data yuridis tersebut sesuai dengan data yang ada dalam surat ukur dan buku tanah hak yang bersangkutan. ${ }^{4} \mathrm{Di}$ dalam Pasal 4 UUPA dinyatakan bahwa dengan dasar hak menguasai dari negara ditentukan adanya macam-macam hak atas pemukaan bumi. Pemanfaatan tanah tidak hanya terbatas terhadap permukaan tanah saja, tetapi juga lingkup tanah yang ada dibawahnya dan air serta ruang yang ada diatasnya. Didalam permukaan tanah yang ada diatasnya dapat dimanfaatkan sepanjang kedalaman permukaan yang dapat digunakan, ketinggian ruang diatas tanah yang boleh digunakan, fungsi tanah sesuai dengan batas wajar, kemampuan secara teknis dari permukaan tanah serta kesanggupan pemegang alas hak tersebut. ${ }^{5}$

Mengingat pentingnya tanah sebagai sebuah objek jaminan kebendaan didalam kredit perbankan, sehingga sudah tentu diikuti dengan lahirnya sebuah lembaga jaminan ${ }^{6}$ yang berkepentingan untuk melindungi para pihak dan/atau subyek hukum tertentu dengan maksud untuk mendapatkan sebuah kepastian hukum tertentu. Berdasarkan hal tersebut, penulis akan membahas terkait Objek jaminan berupa hak milik atas tanah barat, yaitu Hak Eigendom Verponding. Sebelumnya terkait dengan adanya bukti kepemilikan Hak Eigendom Verponding, pada awalnya didalam perjalanan sistem pertanahan nasional sebelum tahun 1960 di Indonesia (atau sebelum berlakunya UUPA), terdapat suatu dualisme hukum. Di satu sisi berlaku hukum-hukum tanah hak kolonial Belanda, yaitu tanah yang tunduk dan patuh terhadap ketentuan Hukum Perdata Barat yang dikenal dengan istilah Tanah Barat atau Tanah Eropa seperti contohnya tanah hak Eigendom, hak Erfpacht, hak Opstal dan tanah barat lainnya yang berlaku ketika itu. Di sisi lain adanya suatu aspek hukum yang berlaku terhadap penguasaan tanah bagi penduduk asli atau bumiputra yang tunduk dan patuh terhadap

\footnotetext{
${ }^{3}$ Ibid.

4 Afifah, Siti Sarah Et.al, (2018). Penggunaan Ruang Bawah Tanah untuk Bangunan Gedung ditinjau dari Peraturan Perundang-Undangan. Jurnal Bina Hukum Lingkungan, 3(1), 53.

5 S.P Sangsun, Florianus, (2008). Tata Cara Mengurus Sertipikat Tanah, Jakarta: Visimedia. hlm. 1.

${ }^{6}$ Lembaga Jaminan memiliki fungsi guna mengatur objek jaminan berupa tanah serta benda-benda lainnya yang melekat pada tanah. Dikutip dari Algifarri Sukmaya, Mohammad. Et.al., (2020). Perlindungan Hukum Bagi Pemenang Lelang Objek Hak Tanggungan Dalam Hal Eksekusi Terhalang Oleh Gugatan Ditinjau Dari Hukum Jaminan. Jurnal Dialogia Iuridica, 11(2), 117.
} 
ketentuan Hukum Adat sehingga tidak mempunyai bukti-bukti tertulis. Alas Hak tersebut biasanya dimiliki oleh penduduk setempat yang dikenal dengan istilah Tanah Adat misalnya tanah milik adat, hak Ulayat, Kikitir, tanah hak Yasan, Petuk, tanah Gogolan dan berbagai macam jenis tanah adat lainnya. ${ }^{7}$

Seluruh tanah hak-hak barat serta hak adat lainnya yang belum melaksanakan konversi menurut ketentuan buku II UUPA mengenai konversi akan berakhir masa berlakunya selambat-lambatnya pada tanggal 24 September 1980. Otomatis setelah lewatnya dari tanggal serta tahun yang telah ditentukan, tanah tersebut dapat dinyatakan sebagai tanah yang dikuasai langsung oleh negara apabila pemilik maupun ahli waris dari alas hak tersebut belum melaksanakan konversi atas tanah yang dimilikinya. Untuk mengantisipasi persoalan hukum yang timbul sebagai akibat dari pembaharuan peraturan agraria nasional, maka pemerintah melalui pengaturan produk hukum terkait konversi menegaskan kembali tentang berakhirnya hak atas tanah, sebagai sebuah prinsip yang ditegaskan di dalam UUPA, dengan maksud dan tujuan agar dapat mengakhiri pemberlakuan hak-hak Barat peninggalan kolonial terhadap alas hak kepemilikan tanah di Indonesia dengan seluruh unsur-unsur yang tidak sepaham dengan asas-asas Demokrasi Pancasila serta Pasal 33 UUD 1945. ${ }^{8}$

Produk hukum terkait yang dikeluarkan pemerintah kala itu dengan mengeluarkan pengaturan didalam Keputusan Presiden Nomor 32 Tahun 1979 tentang Pokok-Pokok Kebijaksanaan Dalam Rangka Pemberian Hak Baru Atas Tanah Asal Konversi Hak Barat (untuk selanjutnya disingkat Kepres 32/1979) serta Peraturan Menteri Dalam Negeri Nomor 3 Tahun 1979 tentang Ketentuan-Ketentuan Mengenai Permohonan dan Pemberian Hak Baru Atas Tanah Asal Konversi Hak-Hak Barat (untuk selanjutnya disebut Permendagri 3/1979). ${ }^{9}$ Oleh karenanya penulis tertarik untuk mengkaji lebih jauh tentang bagaimanakah Kepastian Hukum terkait konversi hak Eigendom Verponding serta Akibat Hukum yang ditimbulkan atas Konversi hak Eigendom Verponding apabila dijadikan sebagai jaminan hak kebendaan.

Berdasarkan latar belakang yang telah dikemukakan tersebut, maka dapat ditentukan dua permasalahan pokok yang akan dikaji dalam penulisan ini yaitu: Bagaimanakah Kepastian Hukum terkait konversi hak Eigendom Verponding,

\footnotetext{
7 Hasanah, Ulfia. (2012). Status Kepemilikan Tanah Hasil Konversi Hak Barat Berdasarkan UU No. 5 Tahun 1960. Jurnal Ilmu Hukum, 2 (2), 201.

${ }^{8}$ Harsono, Budi. (2007). Hukum Agraria Indonesia Jilid I Hukum Tanah Nasional. Jakarta: Djambatan. hlm. 1197.

9 Ibid.
} 
Bagaimanakah Akibat Hukum yang ditimbulkan atas Konversi hak Eigendom Verponding apabila dijadikan sebagai jaminan hak kebendaan.

\section{METODE PENELITIAN}

Penelitian ini memiliki tujuan guna mengkaji mengenai pengaturan konversi terhadap Hak Eigendom Verponding dalam UUPA serta menganalisis dampak yang ditimbulkan atas Konversi hak Eigendom Verponding apabila dijadikan sebagai jaminan hak kebendaan.

Penelitian dilakukan dengan menggunakan metode pendekatan yuridis normatif yang membahas terkait doktrin-doktrin serta asas-asas dalam ilmu hukum didukung dengan spesifikasi penelitian yang digunakan untuk menjawab persoalan-persoalan dalam penulisan ini adalah deskriptif analitis, yaitu analisis data yang didasarkan kepada peraturan-peraturan yang berlaku sebagai norma hukum positif dan data-data lainnya yang kemudian diolah dan diuraikan secara deskriptif sehingga dapat menjawab permasalahan-permasalahan berdasarkan fakta.

Fakta tersebut kemudian dihubungkan dengan ketentuan perundang-undangan yang berlaku, dikaji, dianalisis, dan ditarik kesimpulan yang dapat digunakan untuk menjawab permasalahan yang ada. ${ }^{10}$ Dalam penelitian ini, Penulis menggambarkan dan menganalisis hubungan antara peraturan hukum yang berlaku dengan teori-teori hukum dan praktik pelaksanaan hukum positif yang menyinggung permasalahan mengenai hak Eigendom Verponding sebagai jaminan kebendaan.

\section{PEMBAHASAN}

\section{Kepastian Hukum terkait Konversi Hak Eigendom Verponding}

Mengutip pendapat Kelsen, bahwasanya hukum merupakan sebuah sistemsistem norma yang berlaku, khususnya dalam pembangunan nasional. Fungsi hukum dalam pembangunan nasional tersebut dilandasi oleh Teori Hukum Pembangunan dari Mochtar Kusumaatmadja, bahwa hukum harus bersifat aktif dan digunakan untuk mengubah keadaan dan kondisi tertentu sesuai dengan keinginan masyarakat. ${ }^{11}$ Norma merupakan pernyataan yang menekankan aspek das sollen (yang seharusnya), dengan

\footnotetext{
${ }^{10}$ Amirudin dan Zainal. (2003). Pengantar Metode Penelitan Hukum, Jakarta: PT Raja Grafindo Persada. hlm. 25.

${ }^{11}$ Murwaji, Tarsisius. (2016). Paradigma Baru Hukum Jaminan: Penjaminan Hak Pengelolaan Daratan Perairan Kepulauan Melalui Digitalisasi dan e-Cash Collateral. Padjadjaran Jurnal Ilmu Hukum, 3 (2), 230.
} 
mengaitkan beberapa pengaturan terkait apa yang harus dilakukan guna mencapai suatu kepastian hukum. ${ }^{12}$

Kepastian hukum khususnya didalam praktek hukum agraria nasional telah ditentukan didalam UUPA. Dalam mempelajari sejarah hukum tanah yang diciptakan Belanda, dapat dibagi menjadi 7 (tujuh) periode yang dimulai sejak jaman Vereenigde Oostindische Compagnie (V.O.C) hingga tersusun undang-undang agraria seperti yang sekarang ini berlaku. Pada Tahun 1870 muncul lagi peraturan baru mengenai pertanahan yang disebut dengan Agrarische Wet 1870, dengan berlakunya Agrarische Wet 1870 maka Regeringsreglement 1854 ditambah 5 (lima) ayat baru yang menambah kemungkinan-kemungkinan dalam hal kepemilikan dan penggunaan tanah. Berdasarkan pengaturan tersebut dapat diketahui bahwa hukum tanah telah lahir sejak tahun 1602 dan menjadi dasar ketentuan UUPA pada tahun 1960 yang ditetapkan menjadi ketentuan Hukum Tanah Nasional yang diakui hingga saat ini. ${ }^{13}$ Memasuki tahun 1961 tidak ada lagi tanah yang menurut ketentuannya dapat dikenakan Verponding. Terkait dengan kepastian hukumnya, bahwa hak Eigendom Verponding perlu di konversi sebagaimana ketentuan didalam UUPA. Pengaturan mengenai hak Eigendom itu sendiri terdapat di Buku II Pasal 570 Kitab Undang-Undang Hukum Perdata (untuk selanjutnya disingkat KUHPerdata) dan telah dinyatakan dicabut setelah berlakunya UUPA. Kemudian, Pasal 1 ayat (1) sampai Bagian Kedua Pasal XI UUPA mengatur tentang ketentuan-ketentuan konversi hak atas tanah termasuk didalamnya hak-hak barat terutama Hak Eigendom menjadi sebuah Hak Milik. UUPA tidak secara rinci mengatur mengenai definisi konversi hak atas tanah. Namun, pengertian konversi hak atas tanah itu sendiri sebagaimana pengaturan dari hak-hak tanah yang ada sebelum berlakunya UUPA (dalam hal ini, hak Eigendom) untuk masuk

\footnotetext{
${ }^{12}$ Norma-norma merupakan produk dan aksi manusia yang deliberatif, sedangkan undang-undang yang berisi pengaturan yang bersifat umum harus menjadi pedoman dan pegangan terhadap individu dalam bertingkah laku di lingkungan masyarakat, baik didalam hubungan individu kepada individu lainya maupun dalam hubungan individu dengan masyarakat. Pengaturan tersebut menjadi batasan khususnya terhadap masyarakat dalam melakukan dan/atau memutuskan tindakan terhadap individu. Adanya pengaturan serta pelaksanaannya mengakibatkan suatu hal yang memberikan sebuah kepastian hukum tertentu bagi subyek-subyek hukum lainnya

${ }^{13}$ Dengan berlakunya UUPA, sejak tanggal 24 September 1960 tidak dikenal lagi tanah-tanah hak barat dan tanah-tanah hak milik adat. Lembaganya sudah sudah tidak ada lagi, sedang hak-hak yang ada pun telah dikonversi oleh UUPA menjadi salah satu hak yang baru, dilihat didalam Pasal 24 ayat (1) PP 24/1997 Tentang Pendaftaran Tanah yang mengatur bahwa: "Untuk keperluan pendaftaran hak, hak atas tanah yang berasal dari konversi hak-hak lama dibuktikan dengan alat-alat bukti mengenai adanya hak tersebut berupa bukti-bukti tertulis, keterangan saksi dan/atau, pernyataan yang bersangkutan yang kadar kebenarannya oleh Panitia Ajudikasi dalam pendaftaran tanah secara sistematik atau oleh Kepala Kantor Pertanahan dalam pendaftaran tanah secara sporadik, dianggap cukup untuk mendaftar hak, pemegang hak dan hak-hak pihak lain yang membebaninya."
} 
dalam sistem dari UUPA, yaitu kegiatan untuk menyesuaikan hak-hak atas tanah lama menjadi hak-hak atas tanah baru yang dikenal dalam UUPA. ${ }^{14}$

Pemberlakuan konversi terhadap hak-hak barat (termasuk hak Eigendom) pada saat itu dilakukan dengan pemberian batas jangka waktu sampai 20 tahun sejak pemberlakuan UUPA. Artinya, mensyaratkan terhadap hak atas tanah Eigendom dilakukan konversi menjadi hak milik selambat lambatnya tanggal 24 September 1980.15 Tetapi kenyataannya hingga sampai saat ini masih terdapat tanah-tanah berstatus hak Eigendom yang belum dikonversi, sehingga terhadap tanah yang masih berstatus hak Eigendom tersebut masih dapat dilakukan konversi menjadi hak milik. ${ }^{16}$

Konversi ini sebagai jawaban atas ketidakpastian hukum didalam UUPA yang menyatakan bahwasanya pemberlakuan hak-hak barat wajib untuk dikonversi dengan jangka waktu selama 20 tahun yang berarti setelah tahun 1980, hak-hak barat sudah tidak diakui lagi keberadaannya karena belum melaksanakan konversi. Dengan adanya PP 24/1997, sebagaimana tujuan dari Teori Hukum Pembangunan, maka pengaturan tersebut dimaksudkan untuk memberikan kepastian hukum terhadap masyarakat yang masih memiliki bukti kepemilikan hak barat tersebut sepanjang dapat dibuktikan bukti kepemilikannya ketika proses pendaftaran tanah di Kantor Badan Pertanahan Nasional.

Dalam praktik selama ini, sebelum berlakunya Peraturan Pemerintah Nomor 24 Tahun 1997 tentang Pendaftaran Tanah (untuk selanjutnya disebut PP 24/1997), proses konversi hak atas tanah yang berasal dari hak-hak barat (termasuk Eigendom) dapat langsung dilakukan konversinya sepanjang pemohonnya masih tetap sebagai pemegang hak atas tanah dan merupakan Warga Negara Indonesia serta didalam buktibukti lama tersebut belum beralih ke atas nama orang lain, dan bukti-bukti lainnya terutama Surat Ukur untuk mengetahui batas-batas kepemilikan hak tersebut. Lalu, setelah berlakunya PP 24/1997 mengenai pelaksanaan konversi hak atas tanah tersebut disebut dengan istilah pembuktian hak lama.17 Sehingga berdasarkan ketentuan didalam Pasal 24 Ayat (1) PP 24/ 1997 bahwa untuk keperluan pendaftaran haknya, dibuktikan dengan alat-alat bukti mengenai adanya hak tersebut berupa bukti-bukti tertulis, keterangan saksi dan atau pernyataan pemilik alas hak atas tanah yang

\footnotetext{
${ }^{14}$ Parlindungan, A.P. (1990). Konversi Hak-Hak Atas Tanah. Bandung: Mandar Maju. hlm. 1.

${ }^{15}$ Lubis, Yamin. et.al. (2008). Hukum Pendaftaran Tanah. Bandung: Mandar Maju. hlm. 218.

${ }^{16}$ Idem. hlm. 225.

17 Idem. hlm. 220.
} 
kebenarannya dianggap patut dan cukup beralasan agar dilakukan pendaftaran hak atas tanah. ${ }^{18}$

Namun proses pendaftaran sebagaimana diungkapkan didalam Pasal 24 PP 24/1997 tersebut perlu memperhatikan alat pembuktian yang dimaksud didalam proses pendaftaran hak-hak barat yang belum dikonversi menjadi hak atas tanah yang diakui didalam hukum tanah nasional. Alat Pembuktian yang dimaksud didalam Pasal 24 PP 24/1997 tersebut dijelaskan didalam Peraturan Menteri Negara Agraria/Kepala Badan Pertanahan Nasional Nomor 3 Tahun 1997 Tentang Ketentuan Pelaksanaan Peraturan Pemerintah Nomor 24 Tahun 1997 Tentang Pendaftaran Tanah (untuk selanjutnya disingkat PMNA 3/1997). Didalam Pasal 60 ayat (1) dan (2) menyebutkan:

1. Alat bukti tertulis mengenai kepemilikan tanah berupa alat bukti untuk pendaftaran hak baru dan pendaftaran hak-hak lama sebagaimana dimaksud masing-masing dalam Pasal 23 dan Pasal 24 ayat (1) Peraturan Pemerintah Nomor 24 Tahun 1997.

2. Alat bukti tertulis yang digunakan untuk pendaftaran hak-hak lama sebagaimana dimaksud dalam Pasal 24 ayat (1) Peraturan Pemerintah Nomor 24 Tahun 1997 dinyatakan lengkap apabila dapat ditunjukkan kepada Panitia Ajudikasi dokumendokumen sebagai berikut:

a. Grosse akta hak Eigendom yang diterbitkan berdasarkan Overschrijvings Ordonnantie (S.1834-27), yang telah dibubuhi catatan, bahwa hak Eigendom yang bersangkutan dikonversi menjadi hak milik, atau

b. Grosse akta hak Eigendom yang diterbitkan berdasarkan Overschrijuings Ordonnantie (S.1834-27) sejak berlakunya UUPA sampai tanggal pendaftaran tanah dilaksanakan menurut Peraturan Pemerintah Nomor 10 Tahun 1961 di daerah yang bersangkutan;

Dari beberapa penggalan kalimat didalam pengaturan Pasal 60 PMNA 3/1997 tersebut dapat dinyatakan bahwa tidak semua Hak Eigendom dapat dilakukan pendaftaran tanah sepanjang alat bukti yang dimaksud didalam pasal tersebut dapat dibuktikan. Hak Eigendom yang telah dikonversi sebelum tahun 1980 akan memiliki bukti kepemilikan berupa Grosse Akta hak Eigendom atau lebih dikenal dengan sebutan Acta Van Eigendom. Sehingga bagi kepemilikan grosse akta tersebut dapat dimohonkan

\footnotetext{
${ }^{18}$ Ismail, Ilyas. (2011). Sertifikat Sebagai Alat Bukti Hak Atas Tanah Dalam Proses Peradilan. Kanun Jurnal Ilmu Hukum.
} 13 (1), 21. 
pendaftaran tanah menjadi alas hak yang diakui didalam UUPA setelah dilaksanakan konversi atas hak Eigendom itu sendiri.

Sebelum masuk kedalam tahap konversi, sebelumnya perlu adanya penjelasan bahwasanya Eigendom dan Verponding merupakan dua istilah yang berbeda. Penjelasan terkait istilah "Verponding" didalam literatur pengaturan hukum di Indonesia terdapat didalam Pasal 1 ayat (1) Undang-Undang Nomor 33 Tahun 1953 tentang Penetapan Undang-undang Darurat Nomor 15 Tahun 1952 untuk pemungutan pajak Verponding 1953 serta pengaturan didalam Undang-Undang Nomor 72 Tahun 1958 tentang Pajak Verponding Untuk Tahun-Tahun 1957 dan Berikutnya, yang memberikan pemahaman bahwasanya istilah "Verponding" diperuntukan terhadap salah satu jenis petuk pajak yang dikenakan bagi benda-benda tetap (dalam hal ini tanah) pada saat itu.

Pada Tahun 1952 pajak Verponding terhadap hasil tanah atau lebih dikenal dengan penyebutan Pajak Penghasilan Atas Tanah, dihapuskan oleh pemerintah kala itu. Selanjutnya pada tahun 1959, seluruh pajak hasil bumi ditagihkan dengan nama Iuran Pendapatan Daerah atau dikenal dengan istilah IPEDA, yang merupakan pemungutan pajak oleh pemerintahan pusat tetapi pelaksanaan pemungutan dilakukan oleh otonomi daerah masing-masing dengan maksud untuk membiayai kebutuhan didalam pembangunan didaerah. IPEDA yang tersedia dan dimiliki oleh rakyat kala itu yang belum didaftarkan untuk penggantian hak baru berdasarkan UUPA (konversi), tentu masih berbentuk hak Eigendom dan Petuk Verponding. ${ }^{19}$

Namun didalam prakteknya hingga saat ini pemegang alas hak atas tanah setelah tanggal 24 September 1980 (setelah berlakunya UUPA), masih mempunyai bukti kepemilikan hak atas tanah yang telah dicabut pemberlakuannya oleh Buku Kedua tentang Konversi didalam Pasal I UUPA yaitu berupa hak-hak barat dan hak adat yang belum di konversi, yang sudah pasti akan menimbulkan persoalan hukum baru serta tidak menjamin sebuah kepastian hukum apabila tidak ditentukan didalam pengaturan hukum tanah nasional. Konversi dapat diartikan sebagai perubahan atas hak-hak lama terhadap tanah menjadi alas hak baru yang diakui oleh UUPA. Sehubungan dengan hal tersebut, sebelumnya dapat dijelaskan bahwasanya "hak lama" mengandung pengertian yaitu kepemilikan hak atas tanah sebelum pemberlakuan UUPA, sedangkan hak baru setelah berlakunya UUPA adalah hak-hak atas tanah sebagaimana ditentukan

\footnotetext{
${ }^{19}$ Seven Liadi, William. (2019). Kedudukan Eigendom Verponding Dalam Hukum Pertanahan di Indonesia. Jurnal Panorama
} Hukum. 4 (1), 16. 
oleh UUPA didalam Pasal 16 ayat (1) yaitu Hak Milik (SHM), Hak Guna Usaha (HGU), Hak Guna Bangunan (HGB) dan hak pakai. Sedangkan konversi ini terdiri dari 3 jenis didalam UUPA yaitu konversi terhadap tanah hak Barat, hak adat Indonesia dan Swapraja. ${ }^{20}$

Berdasarkan pembahasan diatas diperoleh kesimpulan bahwa Kepastian Hukum terkait konversi hak Eigendom Verponding telah memiliki kekuatan hukum mengikat dan diakui sebagai bukti kepemilikan Hak atas Tanah dengan ketentuan diperlukan konversi sebagaimana syarat dan ketentuan dalam UUPA. Selanjutnya apakah kegunaan terhadap konversi Hak Eigendom Verponding itu sendiri selain menjamin kepastian hukum hak atas tanah, kegunaan lainnya dari konversi tersebut adalah agar tanah tersebut dapat dijadikan Jaminan Kebendaan sebagaimana ditentukan didalam Undang-Undang Nomor 4 Tahun 1996 Tentang Hak Tanggungan Atas Tanah Beserta Benda-Benda Yang Berkaitan Dengan Tanah (untuk selanjutnya disebut UUHT).

Maka dalam hal ini, penulis berpedoman kepada Teori Hukum Pembangunan yang digunakan guna mencapainya suatu kepastian hukum bagi masyarakat. Kedudukan Hukum dari Hak Eigendom sendiri apabila dijadikan sebuah jaminan dalam pemberian kredit perbankan maka wajib untuk melaksanakan konversi serta pendaftaran menjadi suatu hak milik agar dapat dibebankan Hak Tanggungan sebagaimana pengaturan didalam UUHT. Hal ini dimaksudkan untuk memperkuat kedudukan kreditur sebagai pemegang Hak Tanggungan, karena bagaimanapun juga Hak Eigendom merupakan hak barat yang wajib di konversi agar meminimalkan terjadinya suatu resiko tertentu terhadap kreditur.

\section{Akibat Hukum yang Ditimbulkan atas Konversi Hak Eigendom Verponding apabila dijadikan sebagai Jaminan Hak Kebendaan}

Penggunaan tanah tidak hanya terbatas sebagai tempat tinggal serta tempat untuk bercocok tanam dan lain-lain, tetapi juga dapat digunakan sebagai jaminan kebendaan berupa agunan guna mendapatkan kredit bank dan/atau tanah untuk keperluan jual beli dan sewa menyewa. Begitu pentingnya kegunaan tanah bagi subyek hukum tertentu sehingga menuntut adanya suatu jaminan berupa kepastian hukum atas objek kebendaan tersebut. ${ }^{21}$ Hukum tanah di Indonesia memberikan kepastian hukum terkait

${ }^{20}$ Harsono, Boedi. (2007). Loc. Cit. hlm. 83-84.

${ }^{21}$ S.P Sangsun, Florianus. (2008). Loc. Cit. 
dengan kepemilikan tanah hak Komunal dan hak lain termasuk Hak Eigendom Verponding sepanjang wujud fisiknya masih ada serta dapat dibuktikan keabsahannya. ${ }^{22}$ Jaminan dalam perspektif yuridis dimaknai sebagai salah satu upaya untuk memberikan kepastian hukum kepada kreditor (pihak yang berhak) bahwa debitor (pihak yang memiliki kewajiban) akan melaksanakan kewajibannya. ${ }^{23}$ Dalam arti lain dapat dikatakan bahwa Jaminan sama pemahamannya dengan Agunan Kebendaan, terkait dengan fungsinya untuk melindungi dan memberikan kepastian hukum terhadap kreditur didalam pelunasan piutang debitur.

Kewajiban terkait diperlukannya sebuah jaminan didalam suatu fasilitas kredit tercantum didalam Pasal 1131 Kitab Undang-Undang Hukum Perdata (untuk selanjutnya disingkat KUHPerdata) yang menyebutkan:

“Segala kebendaan si berutang, baik yang bergerak maupun yang tidak bergerak, baik yang sudah ada maupun yang baru akan ada dikemudian hari, menjadi tanggungan untuk segala perikatan perseorangan."

Terkait jaminan kepastian hukum hak atas tanah beserta dengan perkembangan didalam perekonomian nasional, tanah sebagaimana fungsi nya dapat digunakan sebagai Jaminan Hak Kebendaan didalam bentuk Hak Tanggungan Atas Tanah. Hak tanggungan atas tanah merupakan sebuah pembebanan terhadap hak atas tanah yang akan digunakan sebagai objek jaminan kebendaan, hal ini dikarenakan fungsi hak tanggungan tersebut digunakan guna mendapatkan plafond kredit karena tanah dengan beberapa manfaatnya memiliki nilai ekonomis serta nilai ekonomis tersebut selalu meningkat setiap tahunnya. Pembebanan hak tanggungan tersebut haruslah didahului oleh sebuah Perjanjian Kredit guna kepentingan pemberian plafond kredit.

Sebenarnya pengaturan di dalam Pasal 51 Jo. Pasal 57 UUPA, telah terdapat sebuah lembaga penjaminan yang berhubungan dengan jaminan kebendaan terkait dengan hak atas tanah yang dikenal dengan penyebutan Hak Tanggungan (HT) yang merupakan pengganti Hypotheek dan Creedietverband. Namun keberadaan lembaga tersebut baru dapat disahkan setelah penantian panjang selama 34 tahun lamanya yang ditandai dengan keberadaan UUHT pada tanggal 9 April Tahun 1996. Hal tersebut merupakan sebuah penerapan terhadap Pasal 51 Jo. Pasal 57 UUPA. Dengan telah

\footnotetext{
${ }^{22}$ Nurhakim, Lukman Ilman Et.al. (2018). Eksistensi Sertipikat Hak Komunal Atas Tanah Masyarakat Hukum Adat di Sektor Kehutanan dan Perkebunan. Jurnal Bina Hukum Lingkungan. 3 (1), 85.

${ }^{23}$ Abubakar, Lastuti. (2015). Telaah Yuridis Perkembangan Lembaga dan Objek Jaminan (Gagasan Pembaruan Hukum Jaminan Nasional). Jurnal Buletin Hukum Kebanksentralan. 12 (1), 1.
} 
berlakunya UUHT tersebut, HT merupakan satu-satunya lembaga penjaminan terhadap alas hak atas tanah yang diakui didalam pengaturan UUPA. ${ }^{24}$ Menurut UUPA, yang dapat dijadikan jaminan piutang yang dapat dibebankan HT adalah Sertipikat Hak Milik, Hak Guna Usaha dan Hak Guna Bangunan. Sertipikat mempunyai nilai lebih bagi pemegang hak atas tanah, dikarenakan sertipikat merupakan suatu alat bukti tertulis yang paling unggul dibandingkan alat bukti tertulis lainnya. ${ }^{25}$

Tahapan proses pembebanan HT untuk pertama kali dimulai dengan dibuatnya sebuah perjanjian pokok dari sebuah jaminan dalam bentuk perjanjian kredit, setelah proses tersebut pembebanan HT dilaksanakan melalui mekanisme Pembuatan Akta Pemberian Hak Tanggungan (APHT) yang dibuat oleh Pejabat Pembuat Akta Tanah (PPAT). Apabila pemberi HT berhalangan hadir dalam pembuatan APHT dihadapan PPAT, maka cukup dengan membuat Surat Kuasa Membebankan Hak Tanggungan (SKMHT) dan pembuatan kuasa ini sangat bergantung kepada pemberi HT terhadap pihak mana yang akan diberikan kuasa terhadap HT yang dimiliki nya. Pembebanan HT atas tanah-tanah yang belum terdaftar dan/atau belum dikonversi seperti tanah adat, girik, letter $\mathrm{C}$ dan lain-lain, ${ }^{26}$ dapat pula menggunakan SKMHT dalam pembuatan APHT.27

Momen lahirnya HT setelah 34 tahun lamanya merupakan sebuah kejadian yang sangat penting dalam sejarah pengaturan hukum tanah nasional sehubungan dengan munculnya hak tagih preferen dari kreditor atau dikenal dengan istilah kreditur preferrent, dalam hal menentukan posisi dan/atau kedudukan kreditor terhadap kreditor lainnya didalam melaksanakan suatu parate executie salah satunya dengan cara sita jaminan (Conservatoir beslag) terhadap objek jaminan apabila debitur mengalami

\footnotetext{
${ }^{24}$ Harsono, Boedi. (2007). Loc.Cit. hlm. 419.

${ }^{25}$ Kurniati, Nia. (2019). Penataan Penguasaan Tanah Milik Adat Melalui Pelaksanaan Kebijakan Landreform. Jurnal Bina Mulia Hukum Lingkungan. 4(1), 169.

${ }^{26}$ Sebagaimana ketentuan didalam Pasal 10 Ayat 3 UUHT, “ Apabila obyek Hak Tanggungan berupa hak atas tanah yang berasal dari konversi hak lama yang telah memenuhi syarat untuk didaftarkan akan tetapi pendaftarannya belum dilakukan, pemberian Hak Tanggungan dilakukan bersamaan dengan permohonan pendaftaran hak atas tanah yang bersangkutan."

27 Sebagaimana ketentuan didalam Pasal 13 ayat (1) sampai dengan ayat (5) UUHT," (1) Pemberian Hak Tanggungan wajib didaftarkan pada Kantor Pertanahan; (2) Selambat-lambatnya (7) hari kerja setelah penandatanganan Akta Pemberian Hak Tanggungan sebagaimana dimaksud dalam Pasal 10 Ayat (2) UUHT, PPAT wajib mengirimkan Akta Pemberian Hak Tanggungan yang bersangkutan dan warkah lain yang diperlukan kepada Kantor Pertanahan; (3) Pendaftaran Hak Tanggungan sebagaimana dimaksud pada Pasal 13 Ayat (1) UUHT dilakukan oleh Kantor Pertanahan dengan membuatkan buku-tanah Hak Tanggungan dan mencatatnya dalam buku-tanah hak atas tanah yang menjadi obyek Hak Tanggungan serta menyalin catatan tersebut pada sertifikat hak atas tanah yang bersangkutan; (4) Tanggal buku-tanah Hak Tanggungan sebagaimana dimaksud pada Pasal 13 Ayat (3) UUHT adalah tanggal hari ketujuh setelah penerimaan secara lengkap surat-surat yang diperlukan bagi pendaftarannya dan jika hari ketujuh itu jatuh pada hari libur, buku-tanah yang bersangkutan diberi bertanggal hari kerja berikutnya; dan (5) Hak Tanggungan lahir pada tanggal buku-tanah Hak Tanggungan sebagaimana dimaksud pada Pasal 13 Ayat (4) UUHT.
} 
pailit atau mengalami kendala dalam melaksanakan kreditinya. ${ }^{28}$ Sebelum berbicara terkait jaminan, kita perlu memperhatikan terkait pengaturan jaminan di Indonesia. Jaminan secara yuridis dapat dibedakan menjadi 2 (dua) macam, yaitu jaminan materiil (kebendaan) contohnya seperti Gadai (Pand), Credietverband (diatur dalam Stb. 1908 No. 542 sebagaimana telah diubah menjadi Stb. 1937 No. 190), Hipotik (Hyphoteek), Hak Tanggungan serta Fidusia ${ }^{29}$ dan jaminan imateriil (perorangan) seperti Tanggungmenanggung, Penanggungan (Borgtocht) serta Perjanjian Garansi. Didalam praktiknya hingga saat ini yang masih berlaku dan digunakan oleh masyarakat adalah Hak Tanggungan, Hipotik atas kapal laut dan pesawat udara, Tanggung-Menanggung, Gadai, Jaminan Fidusia, Perjanjian Garansi serta Borg. ${ }^{30}$

Sebelumnya Bank dalam memberikan kreditnya wajib mempunyai keyakinan akan kemampuan debitur untuk mengembalikan kredit, sehingga pengertian jaminan disini dalam arti yang luas, karena yang dimaksud jaminan tersebut bukan dalam pengertian yuridis saja tetapi juga dalam pengertian ekonomi. ${ }^{31}$ Menurut Pendapat Sri Soedewi Masjchoen Sofwan memberikan pendapat terkait perbedaan antara pengertian jaminan materiil dan jaminan imateriil. Jaminan materiil memiliki arti yaitu sebuah jaminan yang berupa hak mutlak atas suatu benda yang mempunyai ciri-ciri yang berhubungan langsung atas benda tertentu, dapat dipertahankan terhadap siapapun, selalu mengikuti bendanya dan dapat dialihkan. Sedangkan jaminan imateriil memiliki pemahaman bahwa suatu jaminan yang langsung menimbulkan hubungan secara langsung pada suatu orang tertentu. ${ }^{32}$

Oleh sebabnya perlu kecermatan dari pihak perbankan dalam pemberian kredit, salah satunya yaitu dengan penerapan prinsip kehati-hatian. Dalam tataran

\footnotetext{
${ }^{28}$ Satrio, J. (1998). Hukum Jaminan, Hak Jaminan, Hak Tanggungan, Buku 2. Bandung: Citra Aditya Bakti. hlm. 38.

29 (a) Gadai (pand) diatur di dalam Bab 20 Buku II KUHPerdata; (b) Hipotek diatur didalam Bab 21 Buku II KUHPerdata dalam Pasal 1162 KUHPerdata yang mengandung arti bahwa Hipotik merupakan hak kebendaan atas benda-benda tidak bergerak, untuk mengambil penggantian dari padanya bagi pelunasan suatu perikatan; (c) Credietverband, diatur dalam Stb. 1908 Nomor 542 sebagaimana telah diubah dengan Stb. 1937 Nomor 190, mengandung arti hak kebendaan atas benda-benda untuk menuntut suatu perikatan, dengan adanya credietverband ini memberi kesempatan kepada golongan pribumi yang membutuhkan sejumlah uang untuk meminjam dari lembaga-lembaga kredit; (d) Hak tanggungan adalah hak yang melekat pada suatu tanah yang akan digunakan sebagai objek jaminan sebagaimana dimaksud dalam UUPA; (e) Jaminan fidusia mengandung arti bahwasanya hak jaminan atas suatu benda bergerak, baik yang berwujud maupun yang tidak berwujud dan benda tidak bergerak khususnya bangunan yang tidak dapat dibebani hak tanggungan; dikutip dari HS, Salim. (2011). Perkembangan Hukum Jaminan Di Indonesia, cet 1. Jakarta: PT. Raja Grafindo Persada. hlm. 23-24.

${ }^{30}$ Abubakar, Lastuti. \& Handayani, Tri. (2017). Telaah Yuridis Terhadap Implementasi Prinsip Kehati-hatian Bank Dalam Aktivitas Perbankan Indonesia, Jurnal De lega Lata. 2(1), 79.

${ }^{31}$ Mulyati, Etty \& Aprilianti Dwiputri, Fajrina. (2018). Prinsip Kehati-hatian Dalam Menganalisis Jaminan Kebendaan Sebagai Pengaman Perjanjian Kredit Perbankan. Acta Diurnal. 1(2), 144.

${ }^{32}$ Sofwan, Sri Soedewi Masjchoen. (2007). Hukum Jaminan Indonesia (Pokok-Pokok Hukum Jaminan dan Jaminan Perorangan), cet. 4. Yogyakarta: Liberty. hlm. 46.
} 
implementasi, prinsip kehati-hatian ini diterjemahkan sebagai kewajiban Bank untuk memastikan ketaatan penuh terhadap seluruh regulasi yang berlaku terhadap Bank, termasuk Standard Operating Procedures (SOP) yang dikeluarkan oleh Bank sebagai regulatory compliance. Dengan kata lain, prinsip kehati-hatian ini wajib diterapkan oleh bank baik sebagai lembaga, dalam proses pemberian kredit maupun pembiayaan dan pada organ bank itu sendiri. ${ }^{33}$ Selain itu, Prinsip kehati-hatian merupakan prinsip utama bank dalam memberikan kredit. Istilah serta ruang lingkup pengaturan Prinsip Kehatihatian didalam UU Perbankan dapat ditemukan didalam Pasal 2, Pasal 8, serta Pasal 29 ayat (2), (3), dan (4). Pasal 2 UU Perbankan menyatakan bahwa perbankan Indonesia dalam melakukan usahanya berasaskan demokrasi ekonomi dengan menggunakan prinsip kehati-hatian.

Dari ketentuan tersebut menunjukkan bahwa prinsip kehati-hatian adalah salah satu asas terpenting yang wajib diterapkan atau dilaksanakan oleh bank dalam menjalankan kegiatan usahanya. Hal ini dimaksudkan agar kedudukan kreditur terhadap debitur ketika terjadi kredit macet ${ }^{34}$ menjadi lebih kuat, karena adanya sebuah kepastian hukum didalam hak tanggungan tersebut guna dijadikan sebagai suatu objek jaminan serta kepastian hukum pun dapat diperoleh dengan pembuatan sebuah perjanjian kredit dalam memperoleh plafond kredit. Pelaksanaan pemberian plafond kredit oleh lembaga perbankan diawali dengan adanya suatu perjanjian kredit antara kreditur dengan calon debitur yang merupakan perjanjian riil dengan objek jaminan sebagai acessoir antara kreditur dan debitur. Maka timbul dan berakhirnya perjanjian jaminan bergantung pada perjanjian pokok. Arti riil disini ialah bahwa terjadinya perjanjian kredit ditentukan oleh penyerahan uang oleh Bank kepada nasabah debitur. ${ }^{35}$

Untuk itulah diperlukan suatu itikad baik dari debitur maupun kreditur untuk mencegah kredit macet tersebut. Prinsip itikad baik pada umumnya telah menjadi landasan fundamental bagi pembuatan dan pelaksanaan kontrak, sebab tanpa dilandasi dengan itikad baik para pihak yang terlibat dalam perjanjian mustahil perjanjian itu akan berjalan dengan baik sebagaimana yang telah disepakati bersama. Munculnya asas

\footnotetext{
${ }^{33}$ Abubakar, Lastuti. \& Handayani, Tri. (2017). Op.Cit.

${ }^{34}$ Kredit macet adalah suatu keadaan di mana seorang nasabah tidak mampu membayar lunas kredit bank tepat pada waktunya. Dikutip dari Mulyati, Etty. (2016). Kredit Perbankan-Aspek Hukum dan Pengembangan Usaha Mikro Kecil dalam Pembangunan Perekonomian Indonesia. Bandung: PT. Refika Aditama. hlm. 206.

${ }^{35}$ Djuwityastuti \& Krysna Valayvi, Yunita. (2016). Jaminan Hak Tanggungan Atas Tanah Milik Pihak Ketiga Dalam Perjanjian Kredit di Lembaga Keuangan Perbankan Berdasarkan Undang-Undang Nomor 4 Tahun 1996 Tentang Hak Tanggungan. Jurnal Privat Law. 4(2), 143.
} 
itikad baik ini berawal dari kesepakatan atau persesuaian kehendak yang dibuat oleh para pihak sebagai implementasi dari asas konsensualisme dalam perjanjian/kontrak. ${ }^{36}$ Sebelumnya Bank dalam memberikan kreditnya wajib mempunyai keyakinan akan kemampuan debitur untuk mengembalikan kredit, sehingga pengertian jaminan disini dalam arti yang luas, karena yang dimaksud jaminan tersebut bukan dalam pengertian yuridis saja tetapi juga dalam pengertian ekonomi. ${ }^{37}$

Didalam praktek pelaksanaannya sehubungan dengan pembuatan perjanjian kredit, banyak ditemui calon debitur yang memberikan jaminan tanah dengan alas hak pemegang haknya adalah pihak lain bukan calon debitur tersebut, ${ }^{38}$ sehingga jaminan berupa Hak Tanggungan ini bertujuan untuk memberikan kepastian hukum bagi pemberi kredit yang dijalankan oleh Bank dalam pelaksanaannya. Hak tanggungan ini pun dapat digunakan bank dalam meningkatkan kepercayaan dan kesanggupan dalam hal kemampuan debitur untuk melunasi prestasi yang telah diberikan, dalam arti ketika debitur mengalami gagal bayar, maka hak tanggungan ini pun berguna sebagai jaminan pelunasan untuk kreditur dengan cara Parate Executie.

\section{PENUTUP}

\section{Kesimpulan}

Tanah merupakan hal yang sangat penting dan berguna didalam kehidupan manusia. Sehingga tanah secara ekonomis dapat dijadikan Jaminan Kebendaan sebagaimana ditentukan didalam UUHT. Terkait hak Eigendom Verponding sendiri dapat dijadikan sebagai jaminan kebendaan dan mempunyai kepastian hukum serta memiliki kekuatan hukum mengikat dan diakui sebagai bukti kepemilikan Hak atas Tanah dengan ketentuan diperlukan konversi konversi sebagaimana dituangkan didalam Pasal 25, 33, 39, 51 dan 57 UUPA. Akibat Hukum yang ditimbulkan atas proses konversi tersebut ketika perubahan Hak Eigendom Verponding yang dikonversi sebagaimana ketentuan Pasal 16 ayat (1) UUPA serta ditentukan pula didalam PP 24/1997 terkait Pendaftaran Tanah sehingga memiliki kekuatan hukum mengikat dan dapat dijadikan

\footnotetext{
${ }^{36}$ Agung, I Gusti. (2013). Prinsip Itikad Baik Para Pihak Dalam Perjanjian Kredit Sebagai Upaya Meminimalisasi Terjadinya Kredit Bermasalah Pada Lembaga Keuangan Koperasi. Jurnal Universitas Mataram. 7(2), 58.

${ }^{37}$ Mulyati, Etty. (2016). Loc.Cit.

${ }^{38}$ Dalam hal keterlibatan pihak ketiga dalam perjanjian kredit ini dapat diartikan bahwa pihak ketiga dapat menanggung pelunasan kredit oleh Debitur (Borgtoch), seperti yang dijelaskan dalam Pasal 1820 KUHPerdata yang mengandung arti bahwa penanggungan adalah suatu perjanjian dengan mana melibatakan seorang pihak ketiga, guna kepentingan si berpiutang, mengikatkan diri untuk memenuhi perikatan si berhutang manakala terjadi sebuah wanprestasi, dikutip dari Valayvi, Yunita Krysna. et.al. (2016). Loc.Cit. 143.
} 
jaminan kebendaan sebagaimana tercantum didalam UUHT. Pemberlakuan UUPA sendiri menjadi dasar bahwasanya prinsip status quo hak atas tanah terdahulu memberikan jaminan kepastian hukum dengan ketentuan hak-hak lama menjadi tidak diakui keberadaannya. Bagi pembentuk Undang-Undang terutama Lembaga yang berwenang di dalam sistem hukum pertanahan Nasional, sudah saatnya perlu diadakan sebuah pembaharuan Hukum Agraria Nasional dengan tujuan untuk mempermudah sistem pendaftaran tanah yang selama ini selalu terjadi sengketa diantara kehidupan masyarakat Indonesia. Pembaharuan ini dirasa perlu agar masyarakat dapat memahami sistem hukum pertanahan nasional dengan tetap menjunjung tinggi nilai-nilai moral yang berlaku di masyarakat serta rasa kemanusiaan sebagaimana ditentukan didalam Pasal 33 ayat 3 Undang-Undang Dasar 1945.

\section{DAFTAR PUSTAKA}

\section{Buku}

Amirudin dan Zainal. (2003). Pengantar Metode Penelitan Hukum, Jakarta: PT RajaGrafindo Persada.

Harsono, Budi. (2007). Hukum Agraria Indonesia Jilid I Hukum Tanah Nasional, Jakarta: Djambatan.

HS, Salim. (2011). Perkembangan Hukum Jaminan Di Indonesia, cet 1, Jakarta: PT. Raja Grafindo Persada.

Lubis, Yamin. et.al. (2008). Hukum Pendaftaran Tanah, Bandung: Mandar Maju.

Mulyati, Etty. (2016). Kredit Perbankan-Aspek Hukum dan Pengembangan Usaha Mikro Kecil dalam Pembangunan Perekonomian Indonesia, Bandung: PT. Refika Aditama.

Parlindungan, A.P. (1990). Konversi Hak-Hak Atas Tanah, Bandung: Mandar Maju.

Satrio, J. (1998). Hukum Jaminan, Hak Jaminan, Hak Tanggungan, Buku 2, Bandung: Citra Aditya Bakti.

Sofwan, Sri Soedewi Masjchoen. (2007). Hukum Jaminan Indonesia (Pokok-Pokok Hukum Jaminan dan Jaminan Perorangan), cet. 4, Yogyakarta: Liberty.

S.P Sangsun, Florianus. (2008). Tata Cara Mengurus Sertipikat Tanah, Jakarta: Visimedia. 


\section{Jurnal}

Abubakar, Lastuti. (2015). Telaah Yuridis Perkembangan Lembaga dan Objek Jaminan

(Gagasan Pembaruan Hukum Jaminan Nasional). Jurnal Buletin Hukum Kebanksentralan 12 (1). \& Handayani, Tri. (2017). Telaah Yuridis Terhadap Implementasi

Prinsip Kehati-hatian Bank Dalam Aktivitas Perbankan Indonesia, Jurnal De lega Lata. 2 (1).

Adzini, Danica. (2019). Status Hak Atas Tanah Hasil Okupasi Tentara Nasional Indonesia dan Sertipikat Hak Milik Hasil Konversi" Jurnal Jurist Diction. 2 (4).

Afifah, Siti Sarah Et.al. (2018). Penggunaan Ruang Bawah Tanah untuk Bangunan Gedung ditinjau dari Peraturan Perundang-Undangan. Jurnal Bina Hukum Lingkungan. 3 (1).

Algifarri Sukmaya, Mohammad. Et.al. (2020). Perlindungan Hukum Bagi Pemenang Lelang Objek Hak Tanggungan Dalam Hal Eksekusi Terhalang Oleh Gugatan Ditinjau Dari Hukum Jaminan. Jurnal Dialogia Iuridica. 11 (2).

Agung, I Gusti. (2013). Prinsip Itikad Baik Para Pihak Dalam Perjanjian Kredit Sebagai Upaya Meminimalisasi Terjadinya Kredit Bermasalah Pada Lembaga Keuangan Koperasi. Jurnal Universitas Mataram. 7 (2).

Hasanah, Ulfia. (2012). Status Kepemilikan Tanah Hasil Konversi Hak Barat Berdasarkan UU No. 5 Tahun 1960. Jurnal Ilmu Hukum. 2 (2).

Ismail, Ilyas. (2011). Sertifikat Sebagai Alat Bukti Hak Atas Tanah Dalam Proses Peradilan. Kanun Jurnal Ilmu Hukum. 13 (1).

Kurniati, Nia. (2019). Penataan Penguasaan Tanah Milik Adat Melalui Pelaksanaan Kebijakan Landreform. Jurnal Bina Mulia Hukum Lingkungan. 4 (1).

Mulyati, Etty \& Aprilianti Dwiputri, Fajrina. (2018). Prinsip Kehati-hatian Dalam Menganalisis Jaminan Kebendaan Sebagai Pengaman Perjanjian Kredit Perbankan. Acta Diurnal. 1 (2).

Murwaji, Tarsisius. (2016). Paradigma Baru Hukum Jaminan: Penjaminan Hak Pengelolaan Daratan Perairan Kepulauan Melalui Digitalisasi dan e-Cash Collateral. Padjadjaran Jurnal Ilmu Hukum. 3 (2).

Nugroho, Wahyu. (2017). Rekontruksi Teori Hukum Pembangunan Kedalam Pembentukan Perundang-Undangan Lingkungan Hidup dan Sumber Daya Alam Pasca Reformasi Dalam Bangunan Negara Hukum. Jurnal Legislasi Indonesia. 14 (4). 
Nurhakim, Lukman Ilman Et.al. (2018). Eksistensi Sertipikat Hak Komunal Atas Tanah Masyarakat Hukum Adat di Sektor Kehutanan dan Perkebunan. Jurnal Bina Hukum Lingkungan. 3 (1).

Seven Liadi, William. (2019). Kedudukan Eigendom Verponding Dalam Hukum Pertanahan Di Indonesia. Jurnal Panorama Hukum. 4 (1).

Valayvi, Yunita Krysna. et.al. (2016). Jaminan Hak Tanggungan Atas Tanah Milik Pihak Ketiga Dalam Perjanjian Kredit di Lembaga Keuangan Perbankan Berdasarkan Undang-Undang Nomor 4 Tahun 1996 Tentang Hak Tanggungan. Jurnal Privat Law. 4 (2).

\section{Peraturan Perundang-Undangan}

Undang-Undang Dasar 1945.

Kitab Undang-Undang Hukum Perdata.

Undang-Undang Nomor 5 Tahun 1960 tentang Peraturan Dasar Pokok-Pokok Agraria. Undang-Undang Nomor Nomor 4 Tahun 1996 tentang Hak Tanggungan Atas Tanah Beserta Benda-Benda Yang Berkaitan Dengan Tanah.

Undang-Undang Nomor 10 Tahun 1998 tentang perubahan Undang-Undang Nomor 7 Tahun 1992 tentang Perbankan.

Peraturan Pemerintah Nomor 24 Tahun 1997 tentang Pendaftaran Tanah.

Peraturan Menteri Negara Agraria/Kepala Badan Pertanahan Nasional Nomor 3 Tahun 1997 Tentang Ketentuan Pelaksanaan Peraturan Pemerintah Nomor 24 Tahun 1997 Tentang Pendaftaran Tanah. 